\title{
Exploring Post-Rebel Parties in Power: Political Space and Implications for Islamist Inclusion and Moderation
}

\author{
Lise Storm \\ IAIS, University of Exeter, Exeter, UK \\ Email:1.storm@ex.ac.uk
}

How to cite this paper: Storm, L. (2020). Exploring Post-Rebel Parties in Power: Political Space and Implications for Islamist Inclusion and Moderation. Open Journal of Political Science, 10, 638-667. https://doi.org/10.4236/ojps.2020.104038

Received: August 14, 2020

Accepted: October 7, 2020

Published: October 10, 2020

Copyright $\odot 2020$ by author(s) and Scientific Research Publishing Inc. This work is licensed under the Creative Commons Attribution International License (CC BY 4.0).

http://creativecommons.org/licenses/by/4.0/

\section{(c) (i) Open Access}

\begin{abstract}
This article analyzes factors relating to moderation and immoderation of post-rebel parties in power, thus making a significant departure from previous studies, which have tended to examine these from a position of political weakness. The rigorous analysis marries approaches and findings from comparative politics and Middle East studies with a view to making an original, qualitative contribution to the academic debate on the inclusion of Islamist parties in formal politics based on lessons learned from the experiences of 12 post-rebel parties across the globe, thus also breaking with the trend for single-country case studies or larger, quantitative studies. The research finds that whether post-rebel parties in power are likely to behave moderately largely depends upon the political environment at the time of the conflict's end, i.e., when these parties first gain entry into the formal political system. Post-rebel parties entering a political system with a tradition of resolving political disagreements within the electoral arena, in which the post-rebel party faces rivalry from sizeable competitors, and where the main issue driving the post-rebel party's support during the conflict is no longer salient, are more likely to behave inclusively and remain moderate once in power. With reference to Islamist parties, the issue thus becomes a question of how to best create an environment that facilitates Islamist moderation upon these parties' inclusion into formal politics, rather than a debate over whether the inclusion or exclusion of such parties will lead to their moderation. This finding is likely to significantly change how scholars approach Islamist parties and their inclusion into formal politics.
\end{abstract}

\section{Keywords}

Post-Rebel Parties, Islamist Moderation; Political Space, Power, Inclusion, Competitive Authoritarianism 


\section{Introduction}

Over the past decades, scholars of various disciplines, most notably Middle East politics and terrorism studies, have sought to establish a conceptual framework detailing what constitutes political moderation of radical parties-and in particular of Islamist parties-which is one of the last groups of parties to be allowed entry into contemporary political systems, yet which remains understudied within the field of party politics (Rivetti \& Kraetzschmar, 2018). A substantial part of the scholarly debate has centred on whether the manifestation of moderation should primarily be observed in the form of expressed change of ideology, such as e.g., an official declaration of the abandoning of the use of violent methods, and/or in the form of behavioural change (Clark, 2006; Karakaya \& Yildirim, 2013; Schwedler, 2011). With regard to the latter, a further issue under contestation is the level of observation, that is, whether behavioural change is best observed at the level of individuals or the party as a collective and, furthermore, whether the focus of enquiry ought to be the party members or the party leadership, i.e., the more elite level (Ashour, 2011; Wickham, 2013).

While touching upon behavioural impact, this article is primarily concerned with systemic (environmental) impact, arguing that party moderation is principally determined by the political context. The article raises the fundamental question of under which environmental conditions are the risk of Islamist domination and related immoderation minimized when opening up the political system, focusing on a very specific set of actors, namely post-rebel parties in power in the era from 1990 onwards, i.e., with the onset in earnest of the third wave of democratization (Huntington, 1991) and the sudden and sharp increase in post-rebel party formation (Manning \& Smith, 2019). The article makes a significant contribution to the field by moving away from the traditional debate on radicalization and deradicalization with a view to refocusing - and thus change - the stalled discussion of Islamist inclusion and moderation with the objective of learning lessons from post-rebel parties, which in many instances are also defined as radical, yet are only infrequently discussed in analyses of Islamist parties as a consequence of the reality that the former tend to be located outside of the Middle East and North Africa (MENA). The analysis here consequently centres on entities that have made the transition from armed movements to political parties, the latter defined along the lines of Sartori's (1976: p. 63) classic work as "any political group identified by an official label that presents at elections, and is capable of placing through elections (free or nonfree), candidates for public office". Following this definition, a party can still have an armed wing and does not have to renounce violence, but it must obtain government power within the electoral process in order to qualify (Janda, 1993). Thus, unlike most studies on the topic, this article also covers what is often described as hybrid organizations that operate both as political movements and militant groups (Berti, 2013).

In a further departure from the baseline of many studies, most notably Huntington (1991), in this article, post-rebel parties that have not renounced vi- 
olence are not necessarily defined as what Kirdiş (2018) has termed "immoderate", i.e., the antithesis to moderate. These parties could potentially be ideologically radical, yet behaviourally moderate or vice versa, which is one of the reasons why the term post-rebel parties as opposed to radical, fundamentalist or anti-establishment parties are used here. The article seeks to highlight the reality that the parties in question are not viewed as radical by everyone, nor are all fundamentalist parties radical (Clark \& Schwedler, 2003; Schwedler, 2011). Furthermore, post-rebel parties are also not necessarily anti-establishment. Some of these parties sought to become part of the establishment during their rebel years and prior, but were excluded from electoral processes. Others sought to become the new establishment by ousting the former elite, thus leading to their exclusion from formal politics before some eventually succeeded. The elite-or establishment-they fought against was at times indigenous, but in some cases, it took the form of an external (sometimes colonial) power.

Within the context of post-rebel parties and moderation, the study of such parties in power is a relatively new avenue of research. So far, the debate on moderation has almost exclusively focused on so-called radical parties either on the cusp of gaining entry into formal politics or on post-rebel parties already allowed in, but finding themselves in a position of weakness. This article analyzes post-rebel parties in a position of strength and consequently sheds light on an area that is currently under-studied. Parties that are in power and thus often set the rules themselves, rather than having to moderate to abide by the rules as dictated by other, more powerful, actors. Hence, although moderation is still seen as governed by calculations relating to pluralism, incentives (rewards) and risk as per standard moderation theory (Schwedler, 2011), the parameters of change are different under these circumstances. Moderation is accordingly not defined as a party becoming less ideologically radical in terms of the left-right political spectrum (or, indeed, more advanced multi-dimensional models). Rather, as the actors here determine the rules, the emphasis is on moderation in terms of allowing and affording meaningful political pluralism in practice, i.e., political space ${ }^{1}$. Thus, the article constitutes a significant and original contribution to the conceptual debate with particular emphasis on making headway on the behavioural side of the discussion at the level of the party as a whole, i.e., the collective, although given the personalistic nature of a number of the parties at the core of the analysis, party moderation at the collective level may, in practice, be down to the decisions of individual party leaders.

\section{From Post-Rebel Parties to Islamist Inclusion and Moderation}

Within the disciplines of Middle East politics and terrorism studies, the debate on moderation has largely centred on Islamist entities due to their habitual ex-

${ }^{1}$ Schwedler $(2011,2013)$ argues along the same lines, defining moderation as a move away from exclusionary practices. 
clusion from formal politics for most of the post-independence era ${ }^{2}$. Scholars such as Ashour (2009, 2011), Bayat (2007), Browers (2009), Clark (2006), Norton (1995), Schwedler $(2007,2011,2013)$ and Wickham $(2004,2013)$ have all provided important insights into the workings of and systemic effects upon Islamist parties by way of their inclusion/exclusion from formal politics, i.e., contributing to what has been termed the "inclusion-moderation hypothesis". The inclusion-moderation hypothesis fundamentally seeks to explain the behaviour, ideology and strategies of Islamist movements and parties, the basic assumption being that the integration of such radical/anti-establishment parties into formal (pluralist, but not necessarily democratic) politics will lead to change in the form of moderation of these actors. The focus is, in other words, on change related to the formerly excluded actors, rather than the system more broadly, emphasizing the risk calculations and choices made by the parties in question on the basis of incentives and opportunities offered by the institutional framework in place.

The inclusion-moderation hypothesis is not without its critics, however. Scholars such as Cavatorta and Merone (2013) have argued quite the opposite, namely that exclusion can lead to moderation and thus does not necessarily result in radicalization, whilst others have highlighted problems such as e.g., the reality that the inclusion-moderation hypothesis assumes that the concept of moderation is uncontested amongst scholars, and the reality that it adopts a mechanical and linear approach to change (Al-Anani, 2019; Karakaya \& Yildirim, 2013; Kirdiş, 2018; Pahwa, 2017). Finally, scholars have pointed out that Islamist inclusion does not necessarily result in moderation, nor does it inevitably give rise to democratization (Wegner \& Pellicer, 2009).

At present, the schism between academics who either subscribe to the merits of the inclusion-moderation hypothesis or see it as fundamentally flawed has led to a situation where debate has effectively ceased to exist, with the two sides talking past each other and addressing different audiences. This article is an attempt at reigniting the debate by refocusing and reorienting, learning lessons from the behaviour and experiences of other parties further afield, which were formerly excluded due to what was deemed their radical nature, i.e., their categorization as rebels. In other words, there is a clear affinity between Islamist parties and post-rebel parties in terms of their outsider status, but there are also other similarities. In many instances, post-rebel parties and Islamist parties are located in unstable environments on the verge of violent conflict, often as a result of weak, fragile states ${ }^{3}$ marred by civil war, or they are found in authorita-

\footnotetext{
${ }^{2}$ Much of the work on party moderation in the Middle Eastern context traces its theoretical roots back to studies of formerly excluded socialist and Christian formations that made the transformation into political parties and gained access to the formal political system in Europe and Latin America (Schwedler, 2011). For a thought provoking and recent comparative analysis of the moderation of Islamist and communist parties, please see Karakaya and Yildirim (2013). Please note that within the field of Middle East politics there have also been contributions of a broader nature, i.e., concerned with the effects of inclusion and exclusion beyond Islamist entities. See, among others, Anderson (1997), Ibrahim (1980), Krämer (1994) and Moussalli (1999).

${ }^{3}$ For a critique of the concepts of strong and weak states, please see Giraudy (2019).
} 
rian states where power is largely rooted outside of the electoral arena (Boege, Brown, \& Clements, 2009; Levitsky \& Way, 2010; Schedler, 2006, 2013; van de Walle, 2003). In both types of settings, politics is viewed as a zero-sum game and post-rebel parties and Islamist parties have consequently been categorized as radical or, rather, a threat to the incumbent regime as they have sought to establish themselves as alternatives. Furthermore, both have been assumed to potentially constitute significant political rivals should they be offered the opportunity to enter the formal political system and contest elections on an equal footing with other parties, the post-rebel parties qua their leading role during the conflict situation, and the Islamist parties on the basis of their extensive, institutionalized networks as well as opposition credentials, which were reinforced by the parties' exclusion from formal politics. Hence, these parties-Islamist and post-rebel-were anticipated to be entering the political system from a position of strength, a reality which in the case of the Islamist parties has led to their exclusion from formal politics even in the wake of the introduction of competitive authoritarianism across large parts of the MENA in recent decades (Cavatorta \& Storm, 2018; Cavatorta, Storm, \& Resta, 2020; Rivetti \& Kraetzschmar, 2018).

It is exactly this position of strength, which has preoccupied the thoughts of incumbent regimes and scholars alike, the former in terms of concerns relating to regime survival, i.e., maintaining their own position of power, and the latter with democratization and security issues in mind. As already mentioned, within the disciplines of security studies and Middle East politics, these concerns have given rise to a body of work focusing on Islamist moderation via incentives and what the associated risks to democracy and democratization processes are, i.e., what Huntington (1991: pp. 165-174) terms the "participation/moderation trade-off". With regard to the scholarship on post-rebel parties, the preoccupation with security and democracy has resulted in two sets of literature, the first on the transformation of rebel groups into political parties (Acosta, 2014; Ishiyama \& Batta, 2011; Kovacs, 2007; Kovacs \& Hatz, 2016; Manning, 2007; Matanock, 2017; Sindre, 2016a, 2016b), and the second on the impact of such transformation on party system development, democratization and peace (Ishiyama, 2015; Lyons, 2016; Rudloff \& Findley, 2016; Suazo, 2013). For the most part, and especially during the early years, academics placed particular emphasis on factors relating to the organizational capacities of post-rebel parties during conflict and in the subsequent period of transition, although the study of the institutional environment has been steadily growing in line with the expansion of research on the impact of party change.

A recent contribution to the debate by Manning and Smith (2019: p. 417) explores both organizational and environmental factors in a comparative fashion within the parameters of legislative elections. The analysis centres on the risk-reward ratio "or party leaders contemplating whether and how much to invest in adapting their party's ideological appeals, collective identity or organizational routines, such as candidate selection procedures, in order to win seats", 
working on the basis of the core assumption that parties will only change if forced to do so, either because their own survival or their primary goals are threatened. Like this study, Manning and Smith (2019) are thus concerned with post-rebel parties that have already entered into formal electoral politics at the national level, but the authors do not distinguish between post-rebel parties in a position of strength and those that enter formal politics from a position of weakness given that qua their focus they equate success with the attainment of seats. In contrast to Manning and Smith (2019), who focus on electoral behaviour and post-rebel party change, a recent study by Kirdiş (2018) provides important insights into the conditions under which incumbent Islamist parties resist moderation in terms of affording political space. Accordingly, Kirdiş (2018) explicitly emphasizes strength in her analysis of party change, which centres on the role of internal factors, most notably the lack of willingness to compromise, a sense of moral superiority, and the virtual absence of internal pluralism ${ }^{4}$. Echoing the base premise of Manning and Smith (2019) despite their differing foci, Kirdiş (2018) underlines the importance of necessity when it comes to party change, i.e., that incumbent Islamist parties in the MENA did not moderate because they did not need to as they already dominated the party system.

Combining the main findings and theoretical undercurrents of Manning and Smith (2019) and Kirdiş (2018), with a view to both complement and build upon their work, this article centres its analysis on post-rebel parties that performed well in national elections and secured government power, thus taking charge of decision-making at the highest level, either as the sole governing party or as the leading party in a ruling coalition ${ }^{5}$. It consequently explores the environmental conditions under which these parties obtained and maintained power, where Kirdiş (2018) focuses on the internal and organizational side, whilst also going beyond the legislative arena and, therefore, the scope of Manning and Smith (2019) by including the presidency and other avenues of power. The objective is to learn lessons from the effects of the political environment upon the behaviour of post-rebel parties in power, which can then be applied when discussing the inclusion into formal politics and the prospects for moderation of Islamist parties, whether rebel, post-rebel or simply currently excluded. Because, as the data examined here suggests, contrary to the findings of Manning and Smith (2019) as well as the basic tenet of the inclusion-moderation hypothesis, it is not the timing of national elections, leadership continuity, or inclusion into the formal political system that make post-rebel parties more likely to moderate or, indeed, resist moderation, at least not beyond the electoral arena. Rather, whether a post-rebel party chooses to moderate largely depends on the risk-reward ratio relating to the constellations of power within a particular state, most notably at

${ }^{4}$ Similar observations have been made by Lyons (2016) with reference to post-rebel parties in power in Ethiopia, Rwanda and Uganda.

${ }^{5}$ Schwedler (2011) argues that electoral participation alone is insufficient as an indicator of moderation as parties might still harbour a political agenda that is anything but moderate, i.e., such a move is thus tactical/strategic. 
the point of entry of the post-rebel party into formal politics ${ }^{6}$. In other words, party moderation is principally-albeit not exclusively-determined by the political context.

The following sections explore issues relating to the fundamental research question posed here, namely under which environmental conditions is the risk of Islamist domination and related immoderation minimized when opening up the political system? Section 3 centres on electoral participation and the performance of post-rebel parties at the polls, examining the state of the art of the literature, whilst section 4 builds on these findings and offers a critique from the perspective of post-rebel parties in power as their success is determined by factors that go beyond the electoral arena. Furthermore, section 4 puts forward the argument that an assessment of how post-rebel parties behave once in power must necessarily include an analysis of political space, as dominance is often orchestrated and displayed outside of the electoral arena. Finally, section 5 offers up a discussion and analysis of the implications for the inclusion into formal politics of Islamist parties on the basis of the conclusions reached in sections 3 and 4, highlighting in particular how the focus of the debate ought to shift from a discussion of whether Islamist parties can be included without posing a risk to democracy to a debate on how best to facilitate an environment that minimizes the risk upon their inclusion. In short, the article concludes that based on the lessons learned from post-rebel parties in power elsewhere, the focus should be on the environment, not the individual Islamist actors.

\section{Post-Rebel Party Success at the Polls and the Issue of Political Space}

To explore how different factors, most of them environmental, affect the political moderation of formerly excluded parties entering the political system in a position of strength, the articles makes use of qualitative data relating to post-rebel parties that came to power following their transition from rebel movement to political parties. The case selection was made on the basis of the above-mentioned recent study of the electoral performance by post-rebel parties by Manning and Smith (2019), who identified 77 such parties competing in national legislative elections between 1990 and $2009^{7}$. From this study, 12 cases (see Table 1) were selected for inclusion in the analysis, based on the criterion that the post-rebel party must have won a legislative election and formed government at the national level at least once since entering formal politics. Given the objective of learning lessons from other contexts with a view to refocus the discussion of Islamist inclusion, no Islamist parties were amongst the selected cases.

\footnotetext{
${ }^{6}$ The structure of competition, i.e., electoral systems, presidentialism and territorial arrangements, has been found to influence party success generally, that is, beyond post-rebel parties (Lijphart, 1977; Shugart \& Carey, 1992).

${ }^{7} \mathrm{~A}$ similar approach was taken by Ishiyama (2019), highlighting the ground breaking nature of Manning and Smith's (2019) study, which stands out within the field as there has so far been very little quantitative comparative work published on rebel party transformation and the political success of such parties, although some examination of single cases does exist.
} 
Table 1. Case selection: post-rebel parties in power.

\begin{tabular}{|c|c|c|c|}
\hline Party acronym & Party name & Country & Region \\
\hline ANC & African National Congress & South Africa & Africa \\
\hline CNDD-FDD & $\begin{array}{c}\text { Conseil National pour la Défense } \\
\text { de la Démocratie }\end{array}$ & Burundi & Africa \\
\hline $\mathrm{CPN}(\mathrm{M})$ & Communist Party of Nepal (Maoist Centre) & Nepal & Asia \\
\hline FMLN & $\begin{array}{c}\text { Frente Farabundo Martí para la } \\
\text { Liberación Nacional }\end{array}$ & El Salvador & Latin America \\
\hline FRETILIN & Frente Revolucionária de Timor-Leste & East Timor & Southeast Asia \\
\hline $\mathrm{HDZ}$ & Hrvatska Demokratska Zajednica & Croatia & Balkans \\
\hline MPS & Mouvement Patriotique du Salut & Chad & Africa \\
\hline NRM & $\begin{array}{l}\text { National Resistance Movement } \\
\text { (Harakati za Upinzani za Kitaifa) }\end{array}$ & Uganda & Africa \\
\hline PCT & Parti Congolais du Travail & Congo Brazzaville & Africa \\
\hline PDK & Partia Demokratike e Kosovës & Kosovo & Balkans \\
\hline PPRD & $\begin{array}{c}\text { Parti du Peuple pour la Reconstruction } \\
\text { et la Démocratie }\end{array}$ & DR Congo & Africa \\
\hline RPF & Front Patriotique Rwandais (Inkotanyi) & Rwanda & Africa \\
\hline
\end{tabular}

Taken together, the 12 cases cover a range of orientations, locations and contexts, spanning the left-right spectrum, sub-Saharan Africa, Asia, the Balkans and Latin America, and states teetering on the brink of violent conflict, stable states, democracies with multiparty systems, as well as authoritarian regimes with predominant party systems. The cases thus bring a wealth of experiences to the table, enabling us to chart whether Islamist parties once included into formal politics are likely to moderate and which conditions best facilitate moderation or bolster against immoderation, with the obvious caveat that, given the qualitative nature of the enquiry, while the findings are relevant to the cases included in the analysis, they are not statistically sound. That is not, of course, to say that patterns cannot be detected nor that the results bear no relevance to other post-rebel parties in government or, indeed, to post-rebel parties on the cusp of such power.

\section{A Note on Theory: Party Adaptation beyond Representation}

While there are clear similarities between the post-rebel parties in power and Islamist parties in the MENA as argued previously, the jump made from the study of the moderation of the former to the moderation of the latter is not without difficulties. This reality is largely related to the character of the research done on either set of parties so far, most notably the foci of such. As already discussed, the study of Islamist inclusion has tended to focus on the incentives for such parties to moderate-behaviourally and ideologically-as well as the associated 
risk to pluralist politics, while research on post-rebel parties has long centred on organizational factors, and particularly capabilities, although recent forays into analyses of the institutional environment have emphasized the electoral arena, frequently equating political success to electoral success, i.e., representation, although in some cases this is expanded to inclusion into the executive and, thus, access to patronage resources (Ishiyama, 2019). Consequently, when discussing moderation within this context, the emphasis is on factors that impact upon the likelihood that post-rebel parties will adapt with a view to attract voters (and coalition partners), whilst keeping in mind that parties will only change if forced to do so (Ishiyama, 2019; Kirdiş, 2018; Manning \& Smith, 2019).

But political success and, ultimately, power, goes beyond parliamentary seats. Even if focusing narrowly on the electoral arena, political power is often rooted in the executive and, at times, in seats won at the sub-national level (Ishiyama, 2019; Katz \& Mair, 1995; Kopecky et al., 2012). In authoritarian settings, in states experiencing violent conflict and in those that are recently post-conflict, which are all contexts that apply in the MENA region beyond recently democratic Tunisia, substantial sources of political power are also frequently found outside of the formal political arena, most notably in the form of control of resources, the military (de facto as opposed to de jure) and armed militias, and political power consequently becomes tied to the issue of peace and security (Lyons, 2004; Matfess, 2015; Reilly, 2002; van de Walle, 2003). Taking the different political contexts into consideration, political power is thus best defined here as those factors that affect the structure of competition, including the rules, regulations and processes determining who is the head of state, the head of government, who forms the cabinet, and how these people are (s)elected, in addition to resource control and issue salience at the end of the conflict, a factor which relates to voter mobilization. These elements all play a central role in shaping political moderation and immoderation if thought of as political space and analyzed along the lines of the risk-reward ratio (Ishiyama, 2019; Lijphart, 1977; Shugart \& Carey, 1992).

If accepting that in many instances, power is mainly rooted beyond the electoral arena, and thus adopting a broader view of political success as the attainment and maintenance of power at the national level, there are certain related implications concerning existing findings on the moderation of post-rebel parties in power. Namely, the factors that led to these parties winning seats in the legislature, are not necessarily the same factors that enable post-rebel parties to reach and retain power. In other words, as illustrated in Table 2 and Table 3, it is evident that although factors such as prior political experience, leadership continuity, not being a splinter party, emerging victorious from the conflict, the existence of sizeable, established parties, and the timing of the first post-conflict election explain under which conditions formerly excluded parties are statistically likely to win seats in national elections as per the study by Manning and Smith (2019), they do not appear to account for why some post-rebel parties successful at the polls do better than others on election day. 
Table 2. Post-rebel party success: electoral and other environmental indicators.

\begin{tabular}{|c|c|c|c|c|c|c|c|c|c|c|c|c|}
\hline & RPF & CNDD-FDD & MPS & PCT & PPRD & NRM & ANC & $\mathrm{HDZ}$ & PDK & $\mathrm{CPN}(\mathrm{M})$ & FRETILIN & FMLN \\
\hline Country & RW & BI & TD & CG & $\mathrm{CD}$ & UG & $\mathrm{ZA}$ & HR & XK & NP & TL & SV \\
\hline $\begin{array}{l}\text { Prior political } \\
\text { experience }\end{array}$ & Y & $\mathrm{N}$ & $\mathrm{N}$ & $\mathrm{N} / \mathrm{Y}$ & $\mathrm{N}$ & $\mathrm{N}$ & $\mathrm{Y}$ & $\mathrm{N}$ & $\mathrm{N}$ & Y & $\mathrm{N}$ & $\mathrm{Y}$ \\
\hline $\begin{array}{l}\text { Leadership } \\
\text { continuity }\end{array}$ & $\mathrm{Y}$ & $\mathrm{Y}$ & $\mathrm{Y}$ & $\mathrm{Y} / \mathrm{Y}$ & $\mathrm{Y}$ & $\mathrm{Y}$ & $\mathrm{Y}$ & $\mathrm{Y}$ & $\mathrm{Y}$ & $\mathrm{Y}$ & $\mathrm{Y}$ & $\mathrm{Y}$ \\
\hline Splinter & $\mathrm{N}$ & $\mathrm{N}$ & $\mathrm{N}$ & $\mathrm{N}$ & $\mathrm{N}$ & $\mathrm{N}$ & $\mathrm{N}$ & $\mathrm{N}$ & $\mathrm{N}$ & $\mathrm{Y}$ & $\mathrm{N}$ & $\mathrm{N}$ \\
\hline $\begin{array}{l}\text { Victorious at } \\
\text { conflict end }\end{array}$ & $\mathrm{Y}$ & Y & $\mathrm{Y}$ & $\mathrm{Y} / \mathrm{Y}$ & $\mathrm{Y}$ & $\mathrm{Y}$ & $\mathrm{Y}$ & $\mathrm{Y}$ & $\mathrm{Y}$ & $\mathrm{Y}$ & $\mathrm{Y}$ & $\mathrm{Y}$ \\
\hline $\begin{array}{c}\text { Established rival } \\
\text { parties }^{1}\end{array}$ & $\mathrm{~N}$ & $\begin{array}{l}\text { FRODEBU; } \\
\text { UPRONA }\end{array}$ & $\mathrm{N}$ & $\mathrm{N} / \mathrm{N}$ & $\mathrm{N}$ & $\mathrm{N}$ & NP & $\mathrm{N}$ & $\mathrm{N}$ & $\begin{array}{c}\mathrm{CPN} \\
(\mathrm{UML}) \\
\mathrm{NC}\end{array}$ & $\mathrm{N}$ & PCN \\
\hline $\begin{array}{l}\text { Issue salience } \\
\text { post-conflict }\end{array}$ & $\mathrm{Y}$ & $\mathrm{Y}$ & $\mathrm{Y}$ & $\mathrm{Y}$ & Y & $\mathrm{Y}$ & $\mathrm{Y}$ & $\mathrm{N}$ & $\mathrm{N}$ & $\mathrm{N}$ & $\mathrm{N}$ & $\mathrm{N}$ \\
\hline Election delay & 9 & 0 & 7 & $33 / 3^{*}$ & 3 & 20 & 0 & 0 & 2 & 2 & 3 & 2 \\
\hline $\begin{array}{l}\text { 1st post-conflict } \\
\text { election (leg) }\end{array}$ & 2003 & 2005 & 1997 & $1973 / 2002$ & 2006 & 2006 & 1994 & 1990 & 2001 & 2008 & 2001 & 1994 \\
\hline \multicolumn{13}{|l|}{ Seat share (leg) } \\
\hline 1st election & 41.3 & 54.2 & 52.0 & 100 & 22.2 & 66.8 & 63.0 & 58.4 & 30.0 & 38.1 & 62.5 & 25.0 \\
\hline 2nd election & 45.0 & 76.4 & 72.9 & 100 & 12.4 & 70.1 & 66.5 & 61.6 & 30.0 & 13.9 & 32.3 & 32.1 \\
\hline 3rd election & 46.3 & 63.6 & 44.1 & 100 & $\mathrm{n} / \mathrm{a}$ & 68.8 & 69.8 & 59.1 & 37.0 & 19.3 & 38.5 & 36.9 \\
\hline 4th election & 45.0 & & & 100 & & & 66.0 & 30.5 & 34.0 & & 35.4 & 36.9 \\
\hline 5th election & & & & $14.4^{\mathrm{C}}$ & & & 62.3 & 43.7 & 30.8 & & 35.4 & 38.1 \\
\hline 6th election & & & & $12.0^{\mathrm{C}}$ & & & 57.5 & 43.1 & 19.2 & & & 41.7 \\
\hline 7th election & & & & 38.7 & & & & 29.1 & 20.0 & & & 36.9 \\
\hline 8th election & & & & 34.3 & & & & 33.8 & & & & 36.9 \\
\hline 9th election & & & & 64.0 & & & & 37.7 & & & & 27.4 \\
\hline 10th election & & & & 59.6 & & & & & & & & \\
\hline \multicolumn{13}{|l|}{ Vote share (pres) } \\
\hline 1st election & 95.1 & 94.4 & 69.1 & $\begin{array}{c}- \\
(1992)\end{array}$ & 58.1 & 74.2 & $\mathrm{n} / \mathrm{a}$ & 56.7 & $\mathrm{n} / \mathrm{a}$ & 47.8 & 30.8 & 31.7 \\
\hline 2nd election & 93.1 & 91.6 & 63.2 & $\begin{array}{c}89.4 \\
(2002)\end{array}$ & 49.0 & 69.3 & $\mathrm{n} / \mathrm{a}$ & 61.4 & $\mathrm{n} / \mathrm{a}$ & - & 38.8 & 29.1 \\
\hline 3rd election & 98.8 & 69.4 & 64.7 & 78.6 & 28.8 & 59.3 & $\mathrm{n} / \mathrm{a}$ & 22.5 & $\mathrm{n} / \mathrm{a}$ & - & 57.1 & 35.7 \\
\hline 4th election & & & 88.7 & 60.2 & & 68.4 & $\mathrm{n} / \mathrm{a}$ & 34.1 & $\mathrm{n} / \mathrm{a}$ & & & 51.3 \\
\hline 5th election & & & 59.9 & & & 56.6 & $\mathrm{n} / \mathrm{a}$ & 12.0 & $\mathrm{n} / \mathrm{a}$ & & & 50.1 \\
\hline 6th election & & & & & & & $\mathrm{n} / \mathrm{a}$ & 50.7 & & & & 14.4 \\
\hline 7th election & & & & & & & & 47.3 & & & & \\
\hline
\end{tabular}

Sources. Election data was retrieved from the IPUP arline and IFES databases at http://archive.ipu.org/parline-e/parlinesearch.asp and

http://www.electionguide.org/; ${ }^{1}$ Rival parties are defined as parties winning 10 percent or more in the previous (conflict or pre-conflict) election and also competing in the first post-conflict election (Manning \& Smith, 2019); ${ }^{\star}$ Delay between end of conflict in the first instance and the holding of multi-party (competitive) elections; ${ }^{C}$ Period of conflict; Bold highlights victory for post-rebel party; Grey shaded area shows indicators positively correlated with electoral success according to Manning and Smith (2019); Front for Democracy in Burundi (FRODEBU), Union for National Progress (UPRONA), National Party (NP), Communist Party of Nepal (Unified Marxist-Leninist) (CPN (UML)), Partido de Concertación Nacional (PCN), and the Nepali Congress (NC). 
Table 3. Political space: exclusionary behaviour in perspective.

\begin{tabular}{|c|c|c|c|c|c|c|c|c|c|c|c|c|}
\hline & RPF & CNDD-FDD & MPS & РCT & PPRD & NRM & ANC & $\mathrm{HDZ}$ & PDK & $\mathrm{CPN}(\mathrm{M})$ & FRETILIN & FMLN \\
\hline Country & RW & BI & TD & CG & $\mathrm{CD}$ & UG & $\mathrm{ZA}$ & HR & XK & NP & $\mathrm{TL}$ & SV \\
\hline $\begin{array}{c}\text { Uninterrupted } \\
\text { simultaneous presidential } \\
\text { power and legislative } \\
\text { victory }\end{array}$ & $\mathrm{Y}$ & $\mathrm{Y}$ & $\mathrm{Y}$ & $\mathrm{Y}^{*}$ & $\mathrm{Y}$ & $\mathrm{Y}$ & $\mathrm{Y}$ & $\mathrm{N}$ & $\mathrm{N}$ & $\mathrm{N}$ & $\mathrm{N}$ & $\mathrm{N}$ \\
\hline Party alternated between & & & & & & & & & & & & \\
\hline $\begin{array}{l}\text { government and } \\
\text { opposition }\end{array}$ & $\mathrm{N}$ & $\mathrm{N}$ & $\mathrm{N}$ & $\mathrm{N}$ & $\mathrm{N}$ & $\mathrm{N}$ & $\mathrm{N}$ & $\mathrm{Y}$ & $\mathrm{Y}$ & $\mathrm{Y}$ & $\mathrm{Y}$ & $\mathrm{Y}$ \\
\hline Presidential alternation & $\begin{array}{c}\mathrm{N} \\
\text { Kagame }\end{array}$ & $\begin{array}{c}\mathrm{N} \\
\text { Nkurunziza }\end{array}$ & $\begin{array}{c}\mathrm{N} \\
\text { Déby }\end{array}$ & $\begin{array}{c}\mathrm{N} \\
\text { Nguesso }\end{array}$ & $\begin{array}{c}\mathrm{N} \\
\text { Kabila }\end{array}$ & $\begin{array}{c}\mathrm{N} \\
\text { Museveni }\end{array}$ & $\begin{array}{l}\text { within } \\
\text { party }\end{array}$ & $\mathrm{Y}$ & $\mathrm{Y}$ & $\mathrm{Y}$ & $\mathrm{Y}$ & $\mathrm{Y}$ \\
\hline $\begin{array}{l}\text { Did the post-rebel party } \\
\text { constitute the only legal } \\
\text { party in the country? }\end{array}$ & $\mathrm{N}$ & $\mathrm{N}$ & $\mathrm{N}$ & $\begin{array}{c}\mathrm{Y} \\
\text { Pre-1992 }\end{array}$ & $\mathrm{N}$ & $\mathrm{N}$ & $\mathrm{N}$ & $\mathrm{N}$ & $\mathrm{N}$ & $\mathrm{N}$ & $\mathrm{N}$ & $\mathrm{N}$ \\
\hline $\begin{array}{l}\text { Last pre-conflict election: } \\
\text { no. of parties winning } \\
10 \%+\text { of seats (legislature) }\end{array}$ & 1 & 2 & 0 & 3 & 1 & 0 & 3 & $1^{* *}$ & $1^{* *}$ & 2 & 0 & 2 \\
\hline \multicolumn{13}{|l|}{$\begin{array}{l}\text { Parties winning } 10 \%+ \\
\text { of seats (legislature), } \\
\text { incl. post-rebel party } \\
\text { plus Freedom House } \\
\quad \text { classification }\end{array}$} \\
\hline 1st election & $1(0) \mathrm{N}$ & $3(2) \mathrm{P}$ & $3(2) \mathrm{N}$ & $1(0) \mathrm{P}^{1}$ & $2(1) \mathrm{N}$ & 2(1)P & $3(2) \mathrm{F}$ & 2(1)P & $3(2)$ & $3(1) \mathrm{P}$ & $1(0) \mathrm{P}$ & $3(2) \mathrm{P}^{\mathrm{O}}$ \\
\hline 2nd election & $1(0) \mathrm{N}$ & 2(1)P & $1(0) \mathrm{N}$ & $1(0) \mathrm{N}$ & $1(0) \mathrm{N}$ & $1(0) \mathrm{P}$ & $1(0) \mathrm{F}$ & 2(1)P & $2(1)^{\mathrm{O}}$ & $3(1) \mathrm{P}^{\mathrm{O}}$ & $4(2) \mathrm{P}^{\mathrm{O}}$ & $4(3) \mathrm{F}^{\mathrm{O}}$ \\
\hline 3rd election & $1(0) \mathrm{N}$ & $2(0) \mathrm{N}$ & $1(0) \mathrm{N}$ & $1(0) \mathrm{N}$ & $\mathrm{n} / \mathrm{aN}$ & $1(0) \mathrm{N}$ & $2(1) \mathrm{F}$ & $1(0) \mathrm{P}$ & $4(2)$ & 3(1)P & $3(2) \mathrm{P}^{\mathrm{O}}$ & $3(2) \mathrm{F}^{\mathrm{O}}$ \\
\hline 4th election & $1(0) \mathrm{N}$ & & & $1(0) \mathrm{N}$ & & & $2(1) \mathrm{F}$ & $4(3) \mathrm{F}^{\mathrm{O}}$ & 4(3)P & & 4(3)P & $3(2) \mathrm{F}^{\mathrm{O}}$ \\
\hline 5th election & & & & $1(\theta) P^{\mathrm{C}}$ & & & $2(1) \mathrm{F}$ & $2(1) \mathrm{F}$ & 4(3)P & & $2(1) \mathrm{F}^{\mathrm{O}}$ & $3(2) \mathrm{F}^{\mathrm{O}}$ \\
\hline 6th election & & & & $1(0) P^{C}$ & & & $3(2) \mathrm{F}$ & $2(1) \mathrm{F}$ & $3(2) \mathrm{P}$ & & & $3(2) \mathrm{F}$ \\
\hline 7th election & & & & $1(0) \mathrm{P}^{2}$ & & & & $2(1) F^{\circ}$ & $4(3) \mathrm{P}^{\mathrm{O}}$ & & & $3(1) \mathrm{F}$ \\
\hline 8th election & & & & $1(0) \mathrm{N}$ & & & & $3(2) \mathrm{F}$ & & & & $3(1) \mathrm{F}$ \\
\hline 9th election & & & & $1(0) \mathrm{N}$ & & & & $2(1) \mathrm{F}$ & & & & $4(2) \mathrm{F}$ \\
\hline 10th election & & & & $1(0) \mathrm{N}$ & & & & & & & & \\
\hline $\begin{array}{l}\text { Participation in coalition } \\
\text { government }\end{array}$ & Y & Y & Y & $\mathrm{Y}$ & $\mathrm{N}^{* * *}$ & $\mathrm{~N}$ & $\mathrm{Y}$ & $\mathrm{Y}$ & $\begin{array}{c}\mathrm{Y} \\
\text { Incl. as } \\
\text { junior } \\
\text { partner }\end{array}$ & $\begin{array}{l}\mathrm{Y} \\
\text { Incl. as } \\
\text { junior } \\
\text { partner }\end{array}$ & $\mathrm{Y}$ & $\mathrm{N}$ \\
\hline $\begin{array}{l}\text { Serious allegations of } \\
\text { fraud, manipulation } \\
\text { and/or electioneering }\end{array}$ & $\mathrm{Y}$ & $\mathrm{Y}$ & $\mathrm{Y}$ & $\mathrm{Y}$ & $\mathrm{Y}$ & Y & $\mathrm{N}$ & $\mathrm{N}$ & $\mathrm{N}$ & $\mathrm{N}$ & $\mathrm{N}$ & $\mathrm{N}$ \\
\hline
\end{tabular}

${ }^{\mathrm{C}}$ Indicates period of conflict; ${ }^{\circ}$ Indicates that the post-rebel party was in opposition; ${ }^{1} 1973$ election; ${ }^{2} 2002$ election; ${ }^{*}$ Denis Sassou Nguesso was president from 1979-1992 and again from 1997 onwards following his reinstatement with the assistance of Angolan troops. His presidency was thus interrupted for a brief period, but as this was a time of conflict, it has not been counted as such; ${ }^{* *}$ The former Yugoslavia operated with a 1-party system. The ruling party was the League of Communists of Yugoslavia, which was itself a rebel movement prior to making the transition to a political party upon the fall of the monarchy and the liberation from foreign occupation in 1945; ${ }^{* * *}$ In August 2018, the country's first coalition government was sworn in, some seven months after Felix Tshisekedi took over the presidency from Joseph Kabila, who stepped down to become senator for life; Number of parties in opposition to the post-rebel party highlighted in brackets; Grey shaded areas indicate severe restriction of political space by virtue of (engineered) post-rebel party dominance., i.e., exclusionary behaviour; Freedom House classification: $\mathrm{F}=$ free; $\mathrm{P}=$ partly free; $\mathrm{N}=$ not free; Election data retrieved from the IPUP arline and IFES databases at http://archive.ipu.org/parline-e/parlinesearch.asp and http://www.electionguide.org/. 
For instance, our data highlights the reality that several post-rebel parties in sub-Saharan Africa performed exceedingly well in terms of the attainment and maintenance of power on a consistent basis vis-à-vis their counterparts in other regions, and this despite having virtually no prior political experience and the fact that the sub-Saharan African states were generally the ones which delayed the first post-conflict election the most. Furthermore, the data also shows that in the cases where the main issue that attracted voters to the post-rebel party during the conflict remained salient in its aftermath, the post-rebel party-as expected-did not have to moderate in order to perform well at the polls. However, in the cases where the post-rebel parties were forced to adapt to attract voters due to the lack of issue salience post-conflict, there were also signs of moderation in terms of affording political space and therefore opposition parties of some stature. Thus, there is reason to believe that moderation with representation in mente, which is directed at the electorate, is driven by different factors to moderation with the aim of securing (and sustaining) political power, particularly in post-conflict situations teetering on the brink of violence and in authoritarian contexts, where the electoral arena-which, as discussed above, extends to the objective of being included in the executive, and accordingly appealing to other parties-is often not the ultimate source of such power. Consequently, the arena of contestation is of crucial importance if we are to understand party moderation and inclusive behaviour.

\section{Arenas of Power, Problem Solving and Moderation}

The data presented in Table 3 also illustrates how amongst the 12 cases selected for analysis in this article, seven managed to carve out a predominant position for themselves within their respective political systems. These seven parties-the ANC in South Africa, the CNDD-FDD in Burundi, the MPS in Chad, the NRM in Uganda, the PCT in Congo-Brazzaville, the PPRD in the Democratic Republic of Congo and the RPF in Rwanda, have all enjoyed simultaneous presidential power and legislative victory without interruption (excluding periods of violent unrest) for the duration of the entire post-conflict period, and have thus neither alternated between government and opposition, nor has there been alternation at the level of the presidency, save for in the case of South Africa, where there was a transfer of power within the ANC. This observation is noteworthy as the data also reveals a clear relationship between moderation and power-and predominance specifically - with the most powerful parties having restricted political space the most compared to other post-rebel parties as hinted at above, but not necessarily if measured against the previous regime. In other words, the predominant post-rebel parties have been the least moderate, but have not necessarily immoderated. In fact, in most cases, the post-rebel party has constituted an improvement on the previous regime, having moderated in the sense of replacing one-party systems void of formal opposition parties with a severely restricted form of competitive authoritarianism. 
That said, it is also worth noting the nuances. Most importantly, not all predominant post-rebel parties were met with insignificant opposition from the outset, which was the case in point for the ANC and the CNDD-FDD, and not all predominant post-rebel parties in power restricted political space, with the ANC being the most inclusive. In other words, the existence of significant political rivals did not prevent predominance, and predominance did not necessarily lead to exclusionary behaviour, i.e., in which the post-rebel party used its privileged position to restrict political space and effectively eradicate the opposition to ensure the survival of its own regime.

\subsection{A History of Violence: Resolving Political Disagreements Outside the Electoral Arena}

If the twin factors of absence of weighty competition and predominance do not explain exclusionary behaviour of post-rebel parties in power, then what does? Delving into qualitative historico-political data on the 12 cases, it becomes evident that, as discussed below, the primary arena of power has significant explanatory power, illustrating how ideas of what are tolerable limitations on power and violations of democratic processes vary depending on a particular country's political tradition of not only solving conflict, but also of the level of liberties. Hence, what constitutes an unacceptable roll-back of rights in the eyes of the citizenry (and to some extent also political rivals and the international community) varies from one setting to another, whereas a history of violence as a means to solve political disagreement is clearly linked to predominant systems, either as a result of immoderation or simply the persistence of authoritarianism once post-rebel parties are in power.

Save for the ANC, in the case of the post-rebel parties that became predominant, there was a history of violence as a means to solve political conflict in their respective countries dating back to the pre-independence era, combined with limited-or no-prior experiences with multiparty democracy and, thus, there was a general acceptance (albeit not unopposed) of these existing rules of the game. All six states had furthermore been plagued by either extensive periods of conflict or successive civil wars, and although the period of unrest had come to an end, the issue that had sustained a backing for the post-rebel party amongst the populace-often rooted in ethnicity and/or regionalism-remained salient and the risk of political violence continued to be an imminent possibility and furthermore also not an anomaly.

In terms of the status of the post-rebel parties, this reality had implications for how they faced and tackled political rivalry at the conflict's end and during their subsequent stint in power. In the case of the MPS, the NRM, the PCT, the PPRD and the RPF, the main battlefield was not the electoral arena, but rather outside formal politics. What kept these parties in power had little to do with their political ideology, vision and behaviour. Rather, what attracted supporters amongst the electorate, convinced coalition partners, and kept rivals at bay were access to 
resources and military capability. In Chad, Congo-Brazzaville, Rwanda, Uganda and the Democratic Republic of Congo, the main post-rebel party was faced with limited and weak opposition from rival political parties from the outset. In the case of the former four, this reality was partly a consequence of the fact that the post-rebel party exerted virtual monopoly on power in the legislative and executive spheres right from the conflict's end as they enjoyed immense popular support $^{8}$ (Anderson \& Fisher, 2016; Clark, 2008; Hansen, 2013; Makara, Rakner, \& Svåsand, 2009; Matfess, 2015; Miles, 1995; Reyntjens, 2013; Samset \& Dalby, 2003; Tripp, 2004; Wilson, 2017) ${ }^{9}$. In all cases, including in those states with charismatic leadership and electorally successful parties, the chief strategy of regime survival employed was nonetheless a combination of brute force and clientelism, a widely popular method amongst so-called weak states across the globe (Boggero, 2009; Hansen, 2013; Jensen \& Wanchekon, 2004, de Waal, 2009; van de Walle, 2003).

Initially, opposition to the regimes of the post-rebel parties was muted, to a large extent because the new governing parties were not viewed as rolling rights and liberties back, but rather expanding political space in comparison to their predecessors. However, as time went by and liberties were curtailed and/or members of the elite came to realize that their political ambitions were unlikely to be fulfilled, opposition grew, which in turn led to increased repression and escalation of violence as such matters were routinely raised outside of the formal political arena. The tensions were not over ideology, but rather over access to resources and, by extension, power, given the clientelistic nature of the state (Hansen, 2013; van de Walle, 2003). Opposition forces were thus not outright prohibited. Rather, because the post-rebel parties once in power had blurred the lines between state and party, private and public, what little opposition existed in these countries at the time of the conflict's end thus became squeezed out as such forces were unable to deliver as were new parties seeking to enter the scene. Smaller opposition parties accordingly existed in most states, but they had no genuine power and it was almost unconceivable that they would ever succeed in becoming powerful ${ }^{10}$. The most likely candidates to rival the regime, which in all

\footnotetext{
${ }^{8}$ It is worth highlighting that the post-rebel parties were frequently enormously popular amongst the electorate, and thus their often sizeable victories are usually genuine, although often boosted by repression, fraud and manipulation as reflected in various election monitoring reports (Cheeseman \& Klaas, 2018; Cheeseman, 2015; Levitsky \& Way, 2010).

${ }^{9}$ In the Democratic Republic of Congo, instead of relying on the strong performance of the PPRD at the polls, the regime was built up around the Kabilas. The PPRD was thus one instrument amongst others utilized by the Kabilas to remain in power, but the main mechanisms of regime survival were repression and patronage, including within the electoral arena, where the Kabilas enticed scores of smaller parties from a party landscape of several hundred into joining an alliance led by the PPRD, which effectively also constituted a client (Vander Weyden, 2007). Unlike the other sub-Saharan post-rebel parties in power, the PPRD's situation is thus much more precarious, particularly as some sizeable opposition parties do exist.

${ }^{10}$ When such parties were on the verge of challenging the post-rebel party in power, such as for instance in the case of the Mouvement Démocratique Républicain (Democratic Republican Movement; MDR) in Rwanda, the post-rebel party moved to have its rival prohibited even in the face of international criticism (Reyntjens, 2013; Samset \& Dalby, 2003).
} 
states was personalistic, were to be found within the post-rebel party as opposed to externally.

The dynamics of power in Burundi and South Africa differed somewhat from those of the other five sub-Saharan states in that the ANC and the CNDD-FDD faced rivalry that could not be ignored at the time of the conflict's end, but the shape of the competition took very different forms and so did the environment in which politics unfolded in the two states. Beginning with Burundi, at the end of the war, the CNDD-FDD was arguably the country's main political party, having been the dominant rebel force during the conflict. Thus, the CNDD-FDD controlled the security apparatus and state resources, and despite the signing of a peace agreement, the distribution of power and patronage along ethnic ( $\mathrm{Hu}$ tu/Tutsi) lines, i.e., the issue which had led to the eruption of the war and garnered support for the post-rebel party during the period of conflict, remained salient. Hence, the CNDD-FDD emerged from the war in a strong position vis-à-vis its political opponents, yet the party was not in a position to eradicate its rivals on the party scene as a number of these controlled their own armed militias and had significant as well as stable roots in society, although they were poorly organized (Tobolka, 2014; Wittig, 2016). Consequently, the CNDD-FDD conceded a sizeable seat share in the legislature to opposition parties and entered into a power-sharing arrangement in line with the Arusha agreement, although the CNDD-FDD was firmly in the driving seat (Reyntjens, 1993, 2009; Wittig, $2016)^{11}$. Five years later, at the time of the second post-conflict election in 2010, the CNDD-FDD had cemented its position in power, capitalizing on intra-elite competition and fragmentation of the party system, particularly amongst the Hutu segment and, some say, as a consequence of electoral fraud and manipulation as the international community had become less preoccupied with Burundian affairs (Reyntjens, 2006; Tobolka, 2014). Since the conflict's end in 2005, the CNDD-FDD has thus gradually bolstered its reign by effectively setting up an extensive clientelistic network, thus creating a party-state merger, coupled with harsh repression of any form of opposition-whether ethnic, internal or external-including via the manipulation of legislation with the purpose of interfering with internal party matters of its rivals (Jones \& Wittig, 2016; Lemarchand, 2009; Tobolka, 2014; Wittig, 2016). In other words, the party used the

\footnotetext{
${ }^{11}$ It is worth noting that in many instances, power sharing in the form of coalition government means very little in terms of actually sharing power. In addition to the strategy of entering into coalition government, some predominant post-rebel parties have consciously reduced their seat share in the legislature or effectively given up the presidency as illustrated by the recent example of Joseph Kabila stepping down as the president of the Democratic Republic of Congo. Such behaviour, often termed "tactical moderation" (Karakaya \& Yildirim, 2013) or "strategic moderation" (Schwedler, 2011), frequently occurs in situations where the post-rebel party runs little risk when offering token power, but where the rewards are relatively high, such as for instance under circumstances where the post-rebel party has de facto monopoly on power via e.g., the presidency, command of regional councils, and/or control of the armed forces and police (Cheeseman \& Klaas, 2018). Hence, data indicating a slump at the polls for the post-rebel party does not necessarily imply that the party is not popular or powerful, nor does power-sharing and political contestation necessarily indicate that the party is willing to reach compromise and accept different points of view, one of the key benchmarks often stressed in the academic literature on moderation (Schwedler, 2011).
} 
same regime survival techniques as its compatriots elsewhere in the region, but over a prolonged period of time given that at the outset it was faced with serious contestation, both peaceful and violent.

Whereas in Burundi and the other sub-Saharan states the main arena of contestation was outside formal politics, in South Africa, the electoral arena was where power was anchored. Unlike the other predominant post-rebel parties in power, the ANC did not command a significant military force following the integration into the South African National Defence Force (SANDF) of the party's armed wing, the uMkhonto we Sizwe (Spear of the Nation), in 1994. While the ANC as the governing party was in control of the SANDF, the army was disjointed and weak, and the ANC's real source of power consequently lay elsewhere, i.e., rooted in the electorate. During the struggle against apartheid, the country's racial cleavage had garnered support for the ANC, and that cleavage remained salient post-conflict and therefore continued to recruit supporters and voters for the party (Giliomee, Myburgh, \& Schlemmer, 2001; Southall, 2001). Furthermore, opinion polls also clearly indicated that the rival parties-established and new-were not challenging the ANC's predominant position as black voters continued to vote for the ANC, even when presented with alternatives (Gordon, 2018; Mattes \& Piombo, 2001; Seekings, 2008), whilst the minority electorate remained unconvinced by the party's main rivals (Brooks, 2004; Southern, 2011). Consequently, at the time of the country's first post-conflict election and during the following decades too, the ANC never found itself in a situation where its position of power was significantly challenged, whether within the electoral arena or from outside formal politics, and the party accordingly had no real incentive to restrict political space from a risk-reward perspective. In light of the country's history of multiparty politics, seeking to formally reduce the opposition (i.e., beyond harassment, which the party was certainly guilty of) would arguably have constituted a significant and undoubtedly controversial roll-back and, furthermore, such immoderation and exclusionary behaviour was also unlikely to yield sizeable rewards given the party's already (pre)dominant position (Giliomee, Myburgh, \& Schlemmer, 2001; Southall, 2001).

\subsection{Problem-Solving in the Electoral Arena: Authoritarian and Multiparty Pasts}

In the remaining five cases selected for this study, the post-rebel party secured government power-in most cases at the conflict's end-but did not become predominant, and competition within the party systems was consequently more pronounced than in the seven sub-Saharan cases discussed above. This is not, however, to say that these five cases were necessarily more moderate in orientation. Rather, like the ANC in South Africa, the choices afforded the post-rebel parties in Croatia, East Timor, El Salvador, Kosovo and Nepal, structured-and restricted-their opportunities. 
In Nepal and El Salvador, the CPN(M) and the FMLN were met with fierce competition at the polls from established rival parties, which challenged the position and power of the post-rebel party notwithstanding its victory in the conflict. They were thus not in a position to restrict political space, either because they were not strong enough to do so once in power, as in the case of the $\mathrm{CPN}(\mathrm{M})$ in Nepal, or because they did not gain power until several years after the conflict had ended, like the FMLN in El Salvador. In both cases, the post-rebel party was consequently pushed to change out of necessity. With respect to the $\mathrm{CPN}(\mathrm{M})$, the party was forced to adapt in an effort to attract supporters in the face of competition in the wake of the conflict's end as the issue that had driven the party's backing, i.e., the removal of the monarchy, was no longer salient with the abdication of the king in 2008 (Joshi \& Mason, 2007; Lawoti \& Pahari, 2010) ${ }^{12}$. The FMLNin El Salvador found itself in an even more challenging environment as the basis of power shifted from armed capabilities to the electoral arena at the end of the civil war (1979-1992). Unlike the other post-rebel parties in this study, the FMLN surfaced from the conflictas weak vis-à-vis its main political rivals, most notably the Alianza Republicana Nacionalista (Nationalist Republican Alliance; ARENA), which was already an established, sizeable and highly powerful actor within the formal political system and beyond due to the party's close ties to the military and various militias and, of course, its command of state resources qua the ARENA's position as the ruling party for much of the civil war period (Stanley, 2006). Hence, in order for the FMLN to survive or, as a minimum, remain relevant, the party was forced to change with a view to bolstering its popularity amongst the Salvadorian electorate (Almeida, 2009; Lehoucq, 1995; Lyons, 2010; de Zeeuw, 2010) ${ }^{13}$.

Like the CPN(M) and the FMLN, the FRETILIN, the HDZ and the PDK were forced to adapt, and in the latter three cases also to moderate in order to remain politically relevant. In contrast to the situation in Nepal and El Salvador, in Croatia, East Timor and Kosovo, the conflict had centred around the issue of independence, and the post-rebel parties consequently emerged onto a party scene that resembled a blank canvas. Not in the sense that there were no established or budding rival parties, but rather because none of the parties had contested legislative elections in this new post-independence setting, and in most cases the parties were entirely new to electoral politics due to the authoritarian and/or colonial character of the previous regime. Furthermore, because the post-rebel parties had succeeded in their endeavours, the issue that had attracted supporters to the parties during the struggle for independence was no longer salient.

\footnotetext{
${ }^{12}$ Please note that issues relating to caste, regionalism and ethnicity remained salient post-conflict. ${ }^{13}$ The FMLN won the legislative elections of 2003, but the party did not form government as it was usurped by an alliance between ARENA and the PCN. In El Salvador, as illustrated in table 3, the head of state is also the head of government. At the time of the legislative elections of 2003, the president was Francisco Flores Pérez of the ARENA. From 2003/2009 onwards, the FMLN has succeeded in securing successive legislative and presidential victories, thus in turn forcing the ARENA to adapt its strategies (Holland, 2013; Stanley, 2006; de Zeeuw, 2010).
} 
In East Timor, the FRETILIN was challenged by a great amount of contestation originating from within the party as prominent members left and the FRETILIN splintered-i.e., similar to the situation in Chad/MPS, Congo-Brazzaville/PCT, the Democratic Republic of Congo/PPRD, Rwanda/RPF and Uganda/NRM. Furthermore, the party suffered powerful setbacks in so far as it lost control of the military and police as these factionalized when the country's regional conflict became more prominent following independence (Boyle, 2014; Leach, 2013). In Kosovo, the PDK similarly suffered from a decline in resources and military capabilities as the party adapted to independence, initially under international tutelage. Unlike the war-time situation, where the PDK had been able to rely on illicit funding sources, in the new political context the PDK had to take into account demands for greater accountability and transparency from the public as well as the international community (Manning, 2007) ${ }^{14}$. Furthermore, the PDK was also forced to adapt in terms of ideology-especially with regard to the use of violence-upon the transition from rebel group to political party. This pressure to change was intensified by the rivalry afforded by the Lidhja Demokratike e Kosovës (Democratic League of Kosovo; LDK), which had served as the main vehicle for civil disobedience during the war and therefore had superior roots amongst the citizenry and was also better organized, as well as that of the Aleancapër Ardhmërinë e Kosovës (Alliance for the Future of Kosovo; AAK), which like the PDK originated from within the Kosovo Liberation Army (KLA) and consequently had a similar constituency (Ante, 2010; Cocozzelli, 2013; Manning, 2007; Taylor, 2005).

In other words, whilst the PDK in Kosovo and the HDZ in Croatia-as discussed below-both emerged from their respective conflicts as the main post-rebel force, and although both states originated in the former Yugoslavia, which had operated with a one-party system until the federation began to disintegrate in 1990, both parties faced intense competition at the polls despite party pluralism being relatively new. In Croatia, at the time of the first post-conflict (yet pre-independence) election in 1990, the HDZ faced fierce contestation from the Socijaldemokratska Partija Hrvatske (Social Democratic Party of Croatia; SDP), i.e., the successor to the Savez Komunista Hrvatske (League of Communists of Croatia; SKH), which had governed Croatia within the Yugoslav federation since World War II (Boduszyński, 2010; Ishiyama, 2002). In light of this, the HDZ sought to brand itself as distinctly different to its leftist main rival. Initially, the party generally took a moderate stance with a view to avoid alienating voters and consequently sought to appeal broadly, including to voters on the left, despite the HDZ's conservative character (Haughton \& Fisher, 2008). However, following the HDZ victory in 1990 and party leader Franjo Tuđman's success in the presidential election in 1992, the new regime introduced authoritarian measures to eradicate the opposition, yet the party remained extremely popular amongst the electorate, partly because the opposition was divided and unwilling

${ }^{14}$ This was also the case for the HDZ in Croatia. See Haughton and Fisher (2008). 
to cooperate amongst itself (Bellamy, 2001; Fisher, 2006) ${ }^{15}$. That said, the HDZ's authoritarian tendencies eventually became the party's downfall as some voters came to see the former communist regime as liberal in comparison, and thus the appeal of the left intensified as did that of the centre-right parties, which came across as moderate vis-à-vis the HDZ, and in 2000 the HDZ was consequently relegated to the opposition by the electorate (Bellamy, 2001; Fisher, 2006; Haughton \& Fisher, 2008). Keeping in mind similar situations in the predominant party systems in sub-Saharan Africa, where the roll-back of political rights was accompanied by harsh repression and the restriction of political space as discussed above, the events in Croatia are particularly noteworthy because they demonstrate how the HDZ found itself unable to act similarly to these other post-rebel parties because power was located in a different arena. Not only was the roll-back of liberties a red line for many voters, the attempted use of military force to back up such exclusionary behaviour would also have been unacceptable.

In short, across the five cases (plus South Africa discussed above), despite the diverse political contexts, the reality that political power was anchored and therefore contested within the electoral arena meant that opposition voices were afforded a genuine opportunity to grow and take hold. This, in turn, resulted in alternation of power between different parties becoming the norm over the years in Croatia, East Timor, Kosovo, Nepal and El Salvador, whilst in the predominant states, including South Africa, such alternation did not take place. In the majority of these former states, notwithstanding the multiparty setup, this brought about the establishment of what can best be characterized as 2-party systems ${ }^{16}$, with power alternating in East Timor between the FRETILIN and its main rival, the Congresso Nacional da Reconstrução Timorense (National Congress for Timorese Reconstruction; CNRT), between the FMLN and the ARENA in El Salvador, the HDZ and the SDP in Croatia, and the PDK and the LDK in Kosovo, whilst in Nepal competition is broader and power has consequently alternated between more than two parties.

In these five states plus South Africa, i.e., the ones that did not have a history of violence to resolve conflict but instead saw power anchored in the electoral arena coupled with various degrees of experience with multiparty politics prior to the eruption of their respective conflicts, this state of affairs has continued in the wake of the conflict's end and the rise of the post-rebel parties to power. Furthermore, the ANC, the CPN(M), the FMLN, the FRETILIN, the HDZ and the PDK were generally more inclusive from very early on if compared to the MPS, the NRM, the RPF, the PCT and the PPRD as well as, eventually, the CNDD-FDD, and the former six parties have remained so, albeit with some oscillation. Interestingly, this means that the ANC, the $\mathrm{CPN}(\mathrm{M})$ and the FMLN

${ }^{15}$ The HDZ also targeted the federal government in Belgrade as well as ethnic minorities (especially Serbs and Hungarians) (Haughton \& Fisher, 2008).

${ }^{16}$ Given the character of the party systems, the effective number of parties was of course higher. However, power rested with one of the two dominant parties, which at times included junior coalition partners in the governments. 
have not moderated once in power if benchmarked against the previous (pre-conflict) regime, unlike their remaining counterparts in sub-Saharan Africa (even though these were less inclusive), as well as the FRETILIN, the HDZ and the PDK, thereby underlining the importance of addressing the issue of whether we are concerned with observing change, i.e., the process of moderation, or sustained displays of moderate behaviour ${ }^{17}$. In either case, the analysis above has shown that detailed knowledge of the character of the political environment at the time of the entry of formerly excluded parties into formal politics, most notably the structures of power, is crucial for understanding and assessing the prospects for moderation and moderate (inclusive) behaviour by such parties once in power.

\section{Environmental Constraints and the Behaviour of Post-Rebel Parties in Power: Implications for the Debate on Islamist Inclusion and Moderation}

The study of party change, whether in terms of Islamist moderation by inclusion or the moderation of post-rebel parties within the electoral arena, tend to focus on behavioural and ideological moderation from the perspective of incentives, i.e., risks and rewards. Within this framework, the emphasis has been on how parties respond to-or interact with-the electorate and the incumbent regime, the former in the case of those parties already allowed to partake in formal politics, and the latter with particular reference to the parties that are seeking to join. While such research has taught us a great deal about how formerly excluded parties seek to carve out a position for themselves within pluralist electoral politics based on the risk-reward ratio, they shed little light on how different environments structure the opportunities offered such parties in terms of moderation and immoderation. In other words, these parties do not make their calculations suspended in thin air, but are shaped by various factors relating to the structures of power at the time of inclusion into the formal political system, the historico-political context of the country in question, as well as the risk of violence and insecurity. Offered no such limitations on their power, most parties would become predominant and exclusionary; what prevents this situation from materializing across the globe is the reality that most parties are faced with some limitations, albeit to varying degrees, which in turn explains the different trajectories of post-rebel parties in power. This is a novel angel in the study of formerly excluded parties.

The article has put forward the argument that the historico-political environ-

\footnotetext{
${ }^{17}$ It is worth highlighting that if judged against the post-rebel party's behaviour at the time of gaining power until the present day, this article covers examples that appear to have been moderate from the outset (i.e., from the first post-conflict election), such as e.g., the PDK in Kosovo and El Salvador's FMLN, or have moderated over time in the sense of becoming politically inclusive, one example being the FRETILIN in East Timor. The study also includes post-rebel parties that gained power and which were never moderate and have either remained so (e.g., Rwanda's RPF and the PCT in Congo-Brazzaville) or have experienced backsliding, that is, turning exclusionary once in power, such as for instance Burundi's CNDD-FDD and the MPS in Chad.
} 
ment profoundly shapes the structures of opportunity of formerly excluded parties once in power. That is, the environment largely determines whether a post-rebel party or, indeed, an Islamist party in power is likely to deem moderation the most rewarding or least costly option to maintain their power or whether immoderation or the status quo are better options from a cost-benefit perspective. Furthermore, the article has discussed several factors that appear to influence whether a post-rebel party is likely to behave in an exclusionary fashion, including the character of the political opposition (parties), issue salience, a history of multiparty politics and a tradition of violence to solve conflict. In terms of the 12 post-rebel parties studied here, the qualitative analysis found that the main arena in which power is located and contested, i.e., the electoral arena or outside of formal politics, ultimately shapes how previously excluded parties behave once in power, which is a significant finding for not only the study of post-rebel parties, but also other (formerly) excluded parties, such as e.g., Islamist parties. In terms of those parties which were located within systems where the main arena of contestation was the electoral arena, a post-rebel party's ability to curb political space once in power was limited by the presence of weighty opposition parties at the time of the first post-conflict election, the expectation amongst the electorate that liberties would not be rolled back, and the tacit agreement that democratic procedures-including elections-are the means to resolve disagreements.

The above aligns with the theory put forward by Panebianco (1988) that successful parties adapt to their context or adapt their context to themselves in the sense that post-rebel parties entering systems where the electoral arena was the main source of power, even if the previous regime was authoritarian and/or colonial exclusionary such as in the cases of the HDZ in Croatia, the FRETILIN in East Timor and the PDK in Kosovo, maintain this state of affairs once in power. Furthermore, the analysis also shows that post-rebel parties arriving at power in political systems where political power is mainly anchored outside of the electoral arena, i.e., in clientelism and the use of force, eventually come to rely on such methods to maintain power if not already doing so at the outset, such as for instance in the case of Burundi's CNDD-FDD.

If the analysis of the 12 formerly excluded post-rebel parties here is anything to go by, whether Islamist parties are going to behave moderately-in an inclusive fashion-and also moderate once in power has less to do with ideological positions and incentives at the level of the party and much more to do with the political system and power more broadly, i.e., at the level of the political environment. In other words, this study finds that the issue is not one of how to push such parties ideologically closer towards the centre (Schwedler, 2013), because ideology is secondary in terms of structuring the options available to these parties once in power ${ }^{18}$. This finding has significant implications for the debate on

${ }^{18}$ The 12 post-rebel cases included leftist parties, centrist parties, right wing parties, nationalist parties and ethnic parties. Their ideological anchoring on the left-right continuum did not drive their behaviour. 
Islamist parties and the inclusion-moderation hypothesis, because it underlines the need for change; to look beyond the current focus on inclusion into pluralist systems, as pluralism in itself is a poor predictor of moderate behaviour and moderation, as well as calling for scholars to look beyond the issue of Islamist actors and their risk calculations. In short, scholars ought to query how much is actually up to these Islamist parties in terms of room for change. If parties adapt to their context, are we expecting too much of the Islamist parties, which have not yet been proved immoderate? And are we not expecting enough of the incumbent regimes, which have a clear track-record of exclusionary behaviour, i.e., restricting political space? The majority of Islamist parties seeking to become integrated into the formal political system of their respective countries and operate and contest national elections on an equal footing with other political parties are attempting to gain entry into competitive authoritarian systems where, in most cases, power is located outside of the electoral arena, whether with the military, a non-elected head of state, or a head of state who was (s)elected in elections that were neither free, fair nor genuinely competitive. By virtue of these regimes' restriction of the party landscape, most notably by the exclusion of Islamist parties-whether all or just some-the incumbent regimes are necessarily immoderate. Furthermore, the Islamist parties are not all radical, but in many instances simply constitute the main opposition force rivalling the incumbent regime, thereby earning them their radical label, although many would be better described as rebel parties in their quest for inclusion and, ultimately, power.

With the analysis conducted here in mind, it seems fair to assume that the Islamist parties afforded inclusion into the formal political system in their respective countries will adapt to the structures of power already in place. They are unlikely to immoderate (which none of the 12 cases in this study did) and reverse what Schwedler (2013) once optimistically characterized as democratic openings, but they are also unlikely to switch the main arena of contestation from outside of formal politics to the electoral arena on their own accord, not only due to the fact that they will have adapted to the way of conducting politics under competitive authoritarianism by the time they arrive in power (as they are predicted to do if allowed to contest freely), but also because such a seismic shift takes a so-called democratic moment on par with the Arab Uprisings, which failed to produce such monumental change. What we can thus expect from the inclusion of Islamist parties into formal politics in the competitive authoritarian states of the MENA is for these parties to uphold the status quo, that is, to the extent that these parties will be in a position to make such decisions given that power often does not lie with the political parties and the country's elected representatives. Hence, in comparison to the 12 post-rebel parties analyzed here, the Islamist hopefuls have much less room for manoeuvre because of the nature of the political environment, and their inclusion consequently ought to be less feared, whether by the incumbent regimes or foreign policy makers further 
afield. The formerly excluded Islamist parties are, in other words, in a position of strength given their (anticipated) popularity amongst the electorate, but simultaneously many will find themselves in a position of weakness vis-à-vis the military and/or head of state.

In countries where alternation of power is a genuine possibility, such as for instance in Tunisia and Turkey, where Islamist parties are already participating, the best bulwark against immoderation once in power, which is arguably rare, would have been to improve upon the democratic credentials of the regime prior to the inclusion of these parties because, as discussed above, the electorate and rival parties rarely accept a roll-back of political rights and civil liberties unless backed up with considerable force. In other words, anchoring power in the electoral arena, fostering several strong political parties with popular roots as well as genuinely affording alternation of power at the polls-these are all factors that appear to be conducive of moderate behaviour and moderation according to the findings of this study. This point is not unlike that made by Schwedler (2013: p. 5), who argues that "when institutions are in flux or when institutional checks are not well established to prevent a single-party takeover, the underlying commitments of political actors become extremely relevant', but the approach to the issue is fundamentally dissimilar. Where Schwedler $(2011,2013)$ and other proponents of the inclusion-moderation hypothesis focus on Islamist party change as paramount, this study emphasizes change to the authoritarian political context as a priority, most notably anchoring power in the electoral arena. While this is arguably too late in the cases of Tunisia and Turkey, it is something to bear in mind in other states, most notably those that will have to build new institutions post-conflict, such as e.g., Libya and Syria, in those where the military will one day have to hand power back to a civilian regime (i.e., in Egypt), and in the executive monarchies (especially Jordan, Kuwait and Morocco), where political parties or so-called proto-parties exist, yet democratic political reforms relating to the distribution of power are long overdue. To avoid immoderation, the political environment at the time of entry of the Islamist parties into formal politics ought to be such that predominance is almost impossible, because as Manning and Smith (2019) and Kirdis (2018) underline, parties will only moderate out of necessity, and predominant parties rarely find themselves in such need.

\section{Concluding Remarks}

This article has taken an innovative approach to the discussion and analysis of the perspectives for the moderation of Islamist political parties upon their inclusion into formal politics. Anchoring the rigorous analysis in the literature on post-rebel parties, which shows that such formerly excluded parties, which often enter formal politics from a position of strength, only rarely immoderate. In fact, post-rebel parties tend to adapt to the political environment, with parties entering systems with a history of violence as a means to solve disagreements likely to continue this approach, whilst parties entering systems in which such conflict is 
solved within the electoral arena tend to maintain this strategy. These findings have significant implications for the study of Islamist parties entering formal politics, usually in competitive authoritarian settings. Consequently, the article argues that a shift in focus-from the individual Islamist parties to the environment-is essential if scholars are to accurately assess and predict the consequences and opportunities of Islamist inclusion, whether in terms of moderation and immoderation at the level of the party and/or the political system more broadly. From a policy perspective, particularly with democratization in mind, the question then becomes one of how best to create an environment that facilitates Islamist moderation upon their inclusion, rather than a question of whether the entry of such parties into the system is desirable at all, especially given the authoritarian nature of the incumbent regimes.

\section{Conflicts of Interest}

The author declares no conflicts of interest regarding the publication of this paper.

\section{References}

Acosta, B. (2014). From Bombs to Ballots: When Militant Organizations Transition to Political Parties. Journal of Politics, 76, 666-683. https://doi.org/10.1017/S0022381614000188

Al-Anani, K. (2019). Inclusion-Moderation Thesis: Muslim Brotherhood in Egypt. Oxford Research Encyclopedias. https://oxfordre.com/politics/politics/view/10.1093/acrefore/9780190228637.001.0001/ acrefore-9780190228637-e-1332?rskey $=$ G3kLkT\&result $=20$ https://doi.org/10.1093/acrefore/9780190228637.013.1332

Almeida, P. (2009). Social Movements, Political Parties, and Electoral Triumph in El Salvador. NACLA Report on the Americas, 42, 16-21. https://doi.org/10.1080/10714839.2009.11722215

Anderson, D., \& Fisher, J. (2016). Authoritarianism and the Securitization of Development in Uganda. In T. Hagmann, \& F. Reyntjens (Eds.), Aid and Authoritarianism in Africa (pp. 67-90). London: Zed Books.

Anderson, L. (1997). Fulfilling Prophecies: State Policy and Islamist Radicalism. In J. Esposito (Ed.), Political Islam: Revolution, Radicalism or Reform (pp. 17-31). Boulder: Lynne Rienner.

Ante, A. (2010). State Building and Development: Two Sides of the Same Coin? Exploring the case of Kosovo. Hamburg: Disserta Verlag.

Ashour, O. (2009). The De-Radicalization of Jihadists: Transforming Armed Islamist Movements. London: Routledge. https://doi.org/10.4324/9780203877098

Ashour, O. (2011). Continuity and Change in Islamist Political Thought and Behaviour: Transformations of Armed Islamist Movements in Egypt and Algeria. In B. Korany (Ed.), The Changing Middle East (pp. 139-166). Cairo: American University in Cairo Press. https://doi.org/10.5743/cairo/9789774163531.003.0007

Bayat, A. (2007). Making Islam Democratic: Social Movements and the Post-Islamist Turn. Palo Alto, CA: Stanford University Press.

Bellamy, A. (2001). Croatia after Tudjman: The 2000 Parliamentary and Presidential 
Elections. Problems of Post-Communism, 48, 18-31. https://doi.org/10.1080/10758216.2001.11655948

Berti, B. (2013). Armed Political Organizations: From Conflict to Integration. Baltimore, MD: Johns Hopkins University Press.

Boduszyński, M. (2010). Regime Change in the Yugoslav Successor States. Baltimore, MD: Johns Hopkins University Press.

Boege, V., Brown, M. A., \& Clements, K. (2009). Hybrid Political Orders, Not Fragile States. Peace Review, 21, 13-21. https://doi.org/10.1080/10402650802689997

Boggero, M. (2009). Darfur and Chad: A fragmented Ethnic Mosaic. Journal of Contemporary African Studies, 27, 21-35. https://doi.org/10.1080/02589000802576673

Boyle, M. (2014). Violence after War: Explaining Instability in Post-Conflict States. Baltimore, MD: Johns Hopkins University Press.

Brooks, H. (2004). The Dominant Party System: Challenges for South Africa's Second Decade of Democracy. EISA Occasional Paper No. 25 (October). https://eisa.org.za/pdf/OP25.pdf

Browers, M. (2009). Political Ideology in the Arab World: Accommodation and Transformation. Cambridge: Cambridge University Press. https://doi.org/10.1017/CBO9780511626814

Cavatorta, F., \& Merone, F. (2013). Moderation through Exclusion? The Journey of the Tunisian Ennahda from Fundamentalist to Conservative Party. Democratization, 20, 857-875. https://doi.org/10.1080/13510347.2013.801255

Cavatorta, F., \& Storm, L. (Eds.) (2018). Political Parties in the Arab World. Edinburgh: Edinburgh University Press.

Cavatorta, F., Storm, L., \& Resta, V. (2020). Routledge Handbook of Political Parties in the Middle East and North Africa. London: Routledge. (Forthcoming)

Cheeseman, N. (2015). Democracy in Africa. Cambridge: Cambridge University Press. https://doi.org/10.1017/CBO9781139030892

Cheeseman, N., \& Klaas, B. (2018). How to Rig an Election. New Haven, CT and London: Yale University Press.

Clark, J. (2006). The Conditions of Islamist Moderation: Unpacking Cross-Ideological Cooperation in Jordan. International Journal of Middle East Studies, 38, 539-560. https://doi.org/10.1017/S0020743806412460

Clark, J. (2008). The Failure of Democracy in the Republic of Congo. Boulder, CO: Lynne Rienner.

Clark, J., \& Schwedler, J. (2003). Who Opened the Window? Women's Activism in Islamist Parties. Comparative Politics, 35, 293-313. https://doi.org/10.2307/4150178

Cocozzelli, F. (2013). Between Democratisation and Democratic Consolidation: The Long Path to Democracy in Kosovo. Perspectives on European Politics and Society, 14, 1-19. https://doi.org/10.1080/15705854.2012.732395

de Waal, A. (2009). Mission Without End? Peacekeeping in the African Political Marketplace. International Affairs, 85 , 99-113. https://doi.org/10.1111/j.1468-2346.2009.00783.x

de Zeeuw, J. (2010). "Sons of War": Parties and Party Systems in Post-War El Salvador and Cambodia. In P. Burnell, \& A. Gerrits (Eds.), Promoting Party Politics in Emerging Democracies (pp. 112-137). London: Routledge.

Fisher, S. (2006). Political Change in Post-Communist Slovakia and Croatia: From Nationalist to Europeanist. New York: Palgrave Macmillan. 
https://doi.org/10.1057/9780230600881

Giliomee, H., Myburgh, J., \& Schlemmer, L. (2001). Dominant Party Rule, Opposition Parties and Minorities in South Africa. Democratization, 8, 161-182. https://doi.org/10.1080/714000181

Giraudy, A. (2019). Conceptualizing State Strength: Moving beyond Strong and Weak States. Revista de Ciencia Política, 32, 599-611. https://doi.org/10.4067/S0718-090X2012000300005

Gordon, S. L. (2018). Racial Animosity and Political Party Partisanship in South Africa: The Case of the African National Congress and the Black African majority. Democratization, 25, 351-368. https://doi.org/10.1080/13510347.2017.1365840

Hansen, K. (2013). A Democratic Dictator's Success: How Chad's President Deb Defeated the Military Opposition in Three Years (2008-2011). Journal of Contemporary African Studies, 31, 583-599. https://doi.org/10.1080/02589001.2013.840974

Haughton, T., \& Fisher, S. (2008). From the Politics of State-Building to Programmatic Politics. Party Politics, 14, 435-454. https://doi.org/10.1177/1354068808090254

Holland, A. (2013). Right on Crime? Conservative Party Politics and Mano Dura Policies in El Salvador. Latin American Research Review, 48, 44-67.

https://doi.org/10.1353/lar.2013.0009

Huntington, S. (1991). The Third Wave: Democratization in the Late Twentieth Century. Norman, OK: University of Oklahoma Press.

Ibrahim, S. E. (1980). Anatomy of Egypt's Militant Islamic Groups. International Journal of Middle Eastern Studies, 12, 424-453. https://doi.org/10.1017/S0020743800031238

Ishiyama, J. (2002). A Typology of Communist Successor Parties. In A. Bozóki, \& J. Ishiyama (Eds.), The Communist Successor Parties of Central and Eastern Europe (pp. 271-286). Armonk, NY: M.E. Sharpe. https://doi.org/10.4324/9781003063629-16

Ishiyama, J. (2015). Regime Legacies and Governance in Post-Communist States. Taiwan Journal of Democracy, 11, 1-24.

Ishiyama, J. (2019). Identity Change and Rebel Party Political Success. Government and Opposition, 54, 454-484. https://doi.org/10.1017/gov.2018.48

Ishiyama, J., \& Batta, A. (2011). Swords into Plowshares: The Organizational Transformation of Rebel Groups into Political Parties. Communist and Post-Communist Studies, 44, 369-379. https://doi.org/10.1016/j.postcomstud.2011.10.004

Janda, K. (1993). Comparative Political Parties: Research and Theory. In A. Finifter (Ed.), Political Science: The State of the Discipline II (pp. 163-191). Washington DC: American Political Science Association.

Jensen, N., \& Wanchekon, L. (2004). Resource Wealth and Political Regimes in Africa. Comparative Political Studies, 37, 816-841. https://doi.org/10.1177/0010414004266867

Jones, C., \& Wittig, K. (2016). The 2015 Legislative and Presidential Elections in Burundi: An Unfinished Post-Conflict Transition. Electoral Studies, 43, 206-208. https://doi.org/10.1016/j.electstud.2016.04.012

Joshi, M., \& Mason, D. (2007). Land Tenure, Democracy, and Insurgency in Nepal: Peasant Support for Insurgency Versus Democracy. Asian Survey, 47, 393-414. https://doi.org/10.1525/as.2007.47.3.393

Karakaya, S., \& Yildirim, A. K. (2013). Islamist Moderation in Perspective: Comparative Analysis of the Moderation of Islamist and Western Communist Parties. Democratization, 20, 1322-1349. https://doi.org/10.1080/13510347.2012.696612

Katz, R., \& Mair, P. (1995). Changing Models of Party Organization and Party Democ- 
racy: The Emergence of the Cartel Party. Party Politics, 1, 5-28.

https://doi.org/10.1177/1354068895001001001

Kirdiş, E. (2018). Wolves in Sheep Clothing of Victims of Times? Discussing the Immoderation of Incumbent Islamic Parties in Turkey, Egypt, Morocco, and Tunisia. Democratization, 25, 901-918. https://doi.org/10.1080/13510347.2018.1441826

Kopecky, P., Mair, P., \& Spirova, M. (2012). Party Patronage and Party Government in European Democracies. Oxford: Oxford University Press. https://doi.org/10.1093/acprof:oso/9780199599370.001.0001

Kovacs, M. (2007). From Rebellion to Politics. Stockholm: Uppsala University Department of Government.

Kovacs, M., \& Hatz, S. (2016). Rebel-to-Party Transformations in Civil War Peace Processes 1975-2011. Democratization, 23, 990-1008.

https://doi.org/10.1080/13510347.2016.1159558

Krämer, G. (1994). The Integration of the Integrationist: A Comparative Study of Egypt, Jordan and Tunisia. In G. Salamé (Ed.), Democracy without Democrats? (pp. 229-246). London: I.B. Tauris.

Lawoti, M., \& Pahari, A. (Eds.) (2010). The Maoist Insurgency in Nepal. London: Routledge. https://doi.org/10.4324/9780203869390

Leach, M. (2013). Timor-Leste in 2012: Beyond International Statebuilding? Asian Survey, 53, 156-161. https://doi.org/10.1525/as.2013.53.1.156

Lehoucq, F. (1995). The Elections of the Century in El Salvador. Electoral Studies, 14, 179-183. https://doi.org/10.1016/0261-3794(95)96842-6

Lemarchand, R. (2009). The Dynamics of Violence in Central Africa. Philadelphia, PA: University of Philadelphia Press. https://doi.org/10.9783/9780812202595

Levitsky, S., \& Way, L. (2010). Competitive Authoritarianism: Hybrid Regimes after the Cold War. Cambridge: Cambridge University Press. https://doi.org/10.1017/CBO9780511781353

Lijphart, A. (1977). Democracy in Plural Societies. New Haven, CT: Yale University Press.

Lyons, T. (2004). Post-Conflict Elections and the Process of Demilitarizing Politics: The Role of Electoral Administration. Democratization, 11, 36-62. https://doi.org/10.1080/1351034042000238167

Lyons, T. (2010). Soft Intervention and the Transformation of Militias into Political Parties. In M. Hoddie, \& C. Hartzell (Eds.), Strengthening Peace in Post-Conflict War States (pp. 145-162). Chicago, IL: University of Chicago Press.

Lyons, T. (2016). From Victorious Rebels to Strong Authoritarian Parties: Prospects for Post-War Democratization. Democratization, 23, 1026-1041. https://doi.org/10.1080/13510347.2016.1168404

Makara, S., Rakner, L., \& Svåsand, L. (2009). Turnaround: The National Resistance Movement and the Reintroduction of a Multiparty System in Uganda. International Political Science Review, 30, 185-204. https://doi.org/10.1177/0192512109102436

Manning, C. (2007). Party-Building on the Heels of War: El Salvador, Bosnia, Kosovo and Mozambique. Democratization, 14, 253-272. https://doi.org/10.1080/13510340701245777

Manning, C., \& Smith, I. (2019). Electoral Performance by Post-Rebel Parties. Government and Opposition, 54, 415-453. https://doi.org/10.1017/gov.2018.34

Matanock, A. (2017). Electing Peace: From Civil Conflict to Political Participation. Cambridge: Cambridge University Press. https://doi.org/10.1017/9781316987179 
Matfess, H. (2015). Authoritarianism and the New Politics of African Strong Men. African Studies Review, 58, 181-204. https://doi.org/10.1017/asr.2015.43

Mattes, R., \& Piombo, J. (2001). Opposition Parties and the Voters in South Africa's General Election of 1999. Democratization, 8, 101-128. https://doi.org/10.1080/714000211

Miles, W. (1995). Tragic Tradeoffs: Democracy and Security in Chad. The Journal of Modern African Studies, 33, 53-65. https://doi.org/10.1017/S0022278X0002084X

Moussalli, A. (1999). Moderate and Radical Fundamentalism. Gainesville, FL: University Press of Florida.

Norton, A. R. (1995). The Challenge of Inclusion in the Middle East. Current History, 94, $1-6$.

Pahwa, S. (2017). Pathways of Islamist Adaptation: The Egyptian Muslim Brothers' Lessons for Inclusion Moderation Theory. Democratization, 24, 1066-1084. https://doi.org/10.1080/13510347.2016.1273903

Panebianco, A. (1988). Political Parties. Cambridge: Cambridge University Press.

Reilly, B. (2002). Elections in Post-Conflict Scenarios: Constraints and Dangers. International Peacekeeping, 9, 118-139. https://doi.org/10.1080/714002729

Reyntjens, F. (1993). The Proof of the Pudding is in the Eating: The June 1993 Elections in Burundi. Journal of Modern African Studies, 31, 563-583. https://doi.org/10.1017/S0022278X00012246

Reyntjens, F. (2006). Burundi: A Peaceful Transition after a Decade of War? African Affairs, 105, 117-135. https://doi.org/10.1093/afraf/adi092

Reyntjens, F. (2009). The Great African War: Congo and Regional Geopolitics, 1996-2006. Cambridge: Cambridge University Press. https://doi.org/10.1017/CBO9780511596698

Reyntjens, F. (2013). Political Governance in Post-Genocide Rwanda. Cambridge: Cambridge University Press. https://doi.org/10.1017/CBO9781107338647

Rivetti, P., \& Kraetzschmar, H. (Eds.) (2018). Islamists and the Politics of the Arab Uprisings. Edinburgh: Edinburgh University Press.

Rudloff, P., \& Findley, M. (2016). The Downstream Effects of Combatant Fragmentation on Civil War Recurrence. Journal of Peace Research, 53, 19-32.

https://doi.org/10.1177/0022343315617067

Samset, I., \& Dalby, O. (2003). Rwanda: Presidential and Parliamentary Elections 2003. NORDEM Report 12.

https://www.cmi.no/publications/file/1770-rwanda-presidential-and-parliamentary-ele ctions.pdf

Sartori, G. (1976). Parties and Party Systems: A Framework for Analysis. Cambridge: Cambridge University Press.

Schedler, A. (2006). Electoral Authoritarianism: The Dynamics of Unfree Elections. Boulder, CO: Lynne Rienner.

Schedler, A. (2013). The Politics of Uncertainty: Sustaining and Subverting Electoral Authoritarianism. Oxford: Oxford University Press. https://doi.org/10.1093/acprof:oso/9780199680320.001.0001

Schwedler, J. (2007). Democratization, Inclusion and the Moderation of Islamist Parties. Development, 50, 56-61. https://doi.org/10.1057/palgrave.development.1100324

Schwedler, J. (2011). Can Islamists Become Moderates? Rethinking the Inclusion-Moderation Hypothesis. World Politics, 63, 347-376. https://doi.org/10.1017/S0043887111000050

Schwedler, J. (2013). Islamists in Power: Inclusion, Moderation, and the Arab Uprisings. 
Middle East Development Journal, 5, 1-18. https://doi.org/10.1142/S1793812013500065

Seekings, J. (2008). The Continuing Salience of Race: Discrimination and Diversity in South Africa. Journal of Contemporary African Studies, 26, 1-25. https://doi.org/10.1080/02589000701782612

Shugart, M., \& Carey, J. (1992). Presidents and Assemblies: Constitutional Design and Electoral Dynamics. Cambridge: Cambridge University Press. https://doi.org/10.1017/CBO9781139173988

Sindre, G. (2016a). Internal Party Democracy in Former Rebel Parties. Party Politics, 22, 501-511. https://doi.org/10.1177/1354068814550436

Sindre, G. (2016b). In Whose Interests? Former Rebel Parties and Ex-Combatant Interest Group Mobilisation in Aceh and East Timor. Civil Wars, 18, 192-213. https://doi.org/10.1080/13698249.2016.1205564

Southall, R. (2001). Opposition in South Africa: Issues and Problems. Democratization, 8, 1-24. https://doi.org/10.1080/714000183

Southern, N. (2011). Political Opposition and the Challenges of a Dominant Party System: The Democratic Alliance in South Africa. Journal of Contemporary African Studies, 29, 281-298. https://doi.org/10.1080/02589001.2011.581478

Stanley, W. (2006). El Salvador: State-Building before and after Democratisation, 1980-95. Third World Quarterly, 27, 101-114. https://doi.org/10.1080/01436590500369311

Suazo, A. (2013). Tools of Change: Long-Term Inclusion in Peace Processes. PRAXIS: The Fletcher Journal of Human Security, 28, 5-27.

Taylor, A. (2005). Electoral Systems and the Promotion of "Consociationalism" in a Multi-Ethnic Society. The Kosovo Assembly Elections of November 2001. Electoral Studies, 24, 435-463. https://doi.org/10.1016/j.electstud.2004.09.001

Tobolka, R. (2014). Political Parties in Burundi: Identity and Organizational Cohesion. SSRN Working Paper.

https://poseidon01.ssrn.com/delivery.php?ID=3491151150640880130950931250940930 6404606304804609506502812507612106701502300501910810301304204706012205502 0123088027002115005116054021030082003081071121127115069101086055022027115 0090971011040780830740790261100701041031240231190770950981161150840901268 EXT=pdf https://doi.org/10.2139/ssrn.2483954

Tripp, A. (2004). The Changing Face of Authoritarianism in Africa: The Case of Uganda. Africa Today, 50, 3-26. https://doi.org/10.1353/at.2004.0035

van de Walle, N. (2003). Presidentialism and Clientelism in Africa's Emerging Party Systems. Journal of Modern African Studies, 41, 297-321. https://doi.org/10.1017/S0022278X03004269

Vander Weyden, P. (2007). Founding Elections in the Democratic Republic of Congo: A Highly Fragmented Party System. Journal of African Elections, 6, 203-218. https://doi.org/10.20940/JAE/2007/v6i1a10

Wegner, E., \& Pellicer, M. (2009). Islamist Moderation without Democratization: The Coming of Age of the Moroccan Party of Justice and Development. Democratization, 16, 157-175. https://doi.org/10.1080/13510340802575890

Wickham, C. R. (2004). The Path to Moderation: Strategy and Learning in the Formation of Egypt's Wasat Party. Comparative Politics, 36, 205-228. https://doi.org/10.2307/4150143

Wickham, C. R. (2013). The Muslim Brotherhood. Princeton, NJ: Princeton University Press. 
Wilson, A. (2017). Congo Brazzaville: Political History. Brazzaville: Victoria General Printing.

Wittig, K. (2016). Politics in the Shadow of the Gun: Revisiting the Literature on "Rebel-to-Party Transformations" though the Case of Burundi. Civil Wars, 18, 137-159. https://doi.org/10.1080/13698249.2016.1205561 